\title{
Spor Bilimleri Fakültesi Öğrencilerinin Finansal Okuryazarlık Düzeylerinin Tespiti: Atatürk Üniversitesi Örneği
}

\author{
DOI: 10.26466/opus.601969
}

*

\author{
Sevinç Namlı* - Abdulkadir Kaya** \\ * Dr. Öğr. Üy, Erzurum Teknik Üniversitesi, Spor Bilimleri Fakültesi, Erzurum/Türkiye \\ E-Posta: sevinc.namli@erzurum.edu.tr ORCID: 0000-0003-0958-6792 \\ ** Doç. Dr., Erzurum Teknik Üniversitesi, İiBF İşletme Bölümü, Erzurum/Türkiye \\ E-Posta: akadirkaya@erzurum.edu.tr ORCID: 0000-0001-7789-5461
}

Öz

Çalışmanın amacı, Spor Bilimleri Fakültesi öğrencilerinin finansal okuryazarlık düzeyleri ve finansal tutumların belirlemek, cinsiyet, bölüm ve aylık gelir ile finansal tutumlar arasındaki ilişkiyi tespit etmek ve bölümler arasında bir farklılık olup olmadı̆̆ını analiz etmektir. Bu amaçla Atatürk Üniversitesi Spor Bilimleri Fakültesi bünyesinde yer alan Beden Ĕ̆̈itimi Öğretmenliği, Spor Yöneticiliği, Antrenörlük Ĕ̆itimi ve Rekreasyon bölümlerinde okuyan öğrencilere anket uygulanmıştır. Analize dahil edilen 261 ankete ait veriler frekans ve yüzdeler, Ki-Kare ve Kruskall Wallis analizlerine tabi tutulmuştur. Katılımcıların faiz, nominal - reel faiz ve paranın zaman değeri bilgilerinin yetersiz olduğu, finansal ve ekonomik kavramlardan en fazla kredi kartının $(\% 67,8)$ bilindiği, bileşik faiz $(\% 57,5)$ kavramını hiç duymadıklarım ifade etmişlerdir. Finansal tutumları belirlemek amacıyla hazırlanan 5 li likert sorular arasında Özel veya Bireysel Emeklilik İçin Ödeme Yaparım sorusu en düşük $(2,66)$ cevabı alırken, Faturamı / Yurt Kiramı vb. Harcamalarım Zamanında Öderim sorusu en fazla $(3,74)$ skora sahiptir. Analizler sonucunda spor bilimleri fakültesi öğrencilerinin finansal okuryazarlık düzeylerinin oldukça düşük olduğu ve bölümler arasında bir farklilı̆̆ın olmadığı tespit edilmiştir.

Anahtar Kelimeler: Finansal Okuryazarlık, Finansal Tutum, Spor Bilimleri Fakültesi, Atatürk Üniversitesi 


\title{
The Determination of The Financial Literacy Levels of The Faculty of Sport Sciences Students: Atatürk University Example
}

\begin{abstract}
The aim of the study is to determine the financial literacy levels and financial attitudes of the students of the Faculty of Sports Sciences, to determine the relationship between gender, department and monthly income and financial holdings and to analyze whether there is a difference between the departments. For this purpose, a questionnaire was applied to students who attended Physical Education Teacher Training, Sports Management, Coaching Education and Recreation departments of Atatürk University Sports Sciences Faculty. Data from 261 surveys included in the analysis were subjected to frequency and percentages, Chi-square and Kruskall Wallis analyzes. The participants stated that their knowledge of interest, nominal - real interest and time value of money was insufficient, that most credit card $(67.8 \%)$ was known among the financial and economic concepts and that they never heard of compound interest (57.5\%). Among the 5 likert questions prepared to determine the financial attitudes, I would pay for Private or Private Pension while the lowest $(2,66)$ answer was obtained. The question I Pay My Expenses on Time has the highest score (3.74). As a result of the analysis, it was found that the financial literacy levels of the students of sports sciences were quite low and there was no difference between the departments.
\end{abstract}

Keywords: Financial Litercy, Financial Attitude, Faculty of Sports Sciences, Ataturk University 


\section{Giriş}

Finansal okuryazarlık, yaşanan ekonomik gelişmelerin etkilerini yorumlama becerisi olarak tanımlanabilir (Gerek ve Kurt, 2008). Toplumun her kesimindeki bireyleri etkileyen bu kavramın finansal araçların çeşitlenmesiyle önemi her geçen gün daha da artmaktadır (Temizel ve Bayram, 2011, 73). Günlük yaşamda, bireylerin bütçe yönetimleri, ödemelerin aksatılmadan gerçekleştirilebilmesi veya tasarruflarını ne şekilde değerlendirmesi gerektiği gibi konularda kişinin alacağı doğru kararların finansal okuryazarlık düzeyleri ile doğrusal ilişkisi bulunmaktadır (Lusardi, 2007; Mercan, 2012; Chen ve Volpe, 1998). Bu nedenle yaşamları süresince küçük veya büyük finansal kararlar almak zorunda kalması, bireylerin finansal okuryazarlığı hakkında bilgi sahibi olmasını gerekli kılmaktadır (Gökmen, 2012). Temel düzeyde finansal okuryazar olduğu kabul edilen bir bireyin tasarruf, bütçe, kredi, basit ve bileşik faiz, risk- getiri, enflasyon gibi finansal kavramları bilmesi gerektiği kabul edilmektedir (Alkaya ve Yağlı, 2015). Daha geniş bir açıdan bakıldığında ise ekonomik kararların birey üzerindeki etkilerini bilmek, ekonomiyle ilgili konulara ve kavramlara da hâkim olmak önemli bir kriterdir( Worhington,2006).

Bireylerin sınırsız ihtiyaçlarını karşılamakta isabetli davranışlar sergileyebilmesi başarılı bir ekonomi eğitimiyle olabilmektedir( Yardımcıŏ̆lu vd., 2014). Gelişen finansal piyasalar ve küreselleşme ekonomi bazında kararlar almayı zorlaştırmakta ve geçmişe göre bireyleri daha geniş bir finansal ürün çeşitliliğiyle karşı karşıya bırakmaktadır (Çam ve Barut, 2015). Üretici, tüketici, işveren, çalışan yatırımcı, tasarruf sahibi gibi kimliklerden birine veya birkaçına sahip olduğumuz günümüz dünyasında ekonomi öğrenmeye olan ilgi artmakta ve mecburiyet haline dönüşmektedir (Özer, 2005). Bu nedenle finansal okuryazarlık, kararlarında bireye yardımcı olarak bütçesini yönetebilme yeteneği kazandırmaktadır (Gökmen, 2012). Bütçesini iyi yönden, ekonomik durumunu doğru şekilde değerlendiren, karşılaştığı finansal zorluklar karşısında başarılı mücadele veren bireyin yaşamdan duyulan tatmini artmaktadır (Gönen ve Özmete, 2007).

Finansal refah düzeyinde finansal davranış ve tutumların etkisi yüksektir (Atkinson ve Messy, 2012). Alkaya ve Yağlı'ya göre finansal bilgi düzeyi ile finansal davranış ve tutumlar finansal okuryazarlık düzeyine 
etki etmektedir (Alkaya ve Yağl1, 2015). Kısaca finansal okuryazarlık bireyin finansal bilgisiyle beceri, davranış ve tutularının birleşiminden oluşmaktadır (Sarı̈̈l, 2015). Geleceğe yönelik yatırım yapma veya yapmama isteği, kısa vadeli planlar finansal okuryazarlık düzeyini etkilemektedir. Bu çalışmada, finans eğitimi konularının ele alınmadığı Spor Bilimleri Fakültelerinde okuyan öğrencilerin finansal okuryazarlık düzeyleri tespit edilecektir. Bu amaçla, öğrencilerin finansal konu ve terimler hakkındaki bilgileri, finansal tutumları tespit edilecek ve demografik özellikleri ile finansal tutumları arasında bir ilişkinin olup olmadığı incelenecektir.

\section{Literatür Taraması}

Dışardan karmaşık bir yapı olarak gözüken finansal okuryazarlık, 2008 küresel ekonomik kriz sonrası dünyada ve ülkemizde önemi artmıştır. Alan yazın incelendiğinde ilgili alanda 2008 yılından sonrası yapılan çalışmaların fazlalaştığ görülmektedir. Ekonomi ile ilişkili ders alan iktisadi ve idari bilimler fakültesi öğrencileri üzerine yapılan araştırmaların fazlalığı dikkat çekmektedir.

Er vd. (2017), Mühendislik Fakültesi ile İktisadi ve İdari Bilimler Fakültesi öğrencilerinin finansal okuryazarlık düzeylerini karşılaştırdığı çalışmasında 5 ayrı devlet üniversitesinde öğrenim gören, toplam 824 öğrenciye OECD tarafından geliştirilen anket uygulanmıştır. Araştırmaya katılan öğrencilerinin \%31,7' sinin yüksek, \%30,1' inin orta, \%16 sının ise düşük finansal okuryazarlığa sahip olduğu sonuçlarına ulaşılmıştır.

Contuk (2018), Muğla Sıtkı Koçman Üniversitesi İktisadi ve İdari Bilimler Fakültesinde öğrenim gören ve finansla ilgili dersler alan 327 işletme bölümü öğrencisinin finansal okuryazarlık düzeyleri bazı demografik değiş̧kenler açısından incelediği çalışmasında, öğrencilerin finansal okuryazarlık başarı düzeyleri arasında bir ilişki olup olmadığının belirlemeyi amaçlamıştır. Anket yoluyla topladığı verilerin analizleri sonucunda yatırım bilgisi, faiz, enflasyon gibi sorulara öğrencilerin çoğunluğunun doğru cevap verdiğini ve temel finans okuryazarlık düzeyinde bilgili olduklarını tespit etmiştir. Öğrencilerin borsa, yatırım araçları, yatırım fonları, uzun vade getirisi, hisse senedi- tahvil hakkındaki sorulara ise çoğunlukla yanlış cevap verdiği ve ileri düzeyde finans konusunda daha az bilgi sahibi oldukları sonuçlarını elde etmiştir. 
Başarır ve Saruhan (2017), çalışmalarında Bandırma Onyedi Eylül Üniversitesinde lisans düzeyinde eğitimine devam eden İktisadi ve İdari Bilimler Fakültesi ve Uygulamalı Bilimler Fakültesinde eğitimine devam eden toplam 407 öğrencinin finansal okuryazarlığını tespit etmeyi amaçlamışlardır. İşletme, iktisat, Uluslararası Ticaret ve Lojistik, Maliye ve Ekonometri bölümünde eğitim öğrencilerin finansal okuryazarlık düzeyleri \%58 olarak bulunmuştur. Analiz sonuçlarında Ekonometri bölümünde okuyan öğrencilerde (\%65) finansal okuryazarlık başarılarının en üst seviyede, Uluslararası Ticaret ve Lojistik bölümü öğrencilerinin (\%52) ise finansal okuryazarlık başarı düzeylerinin diğer bölümler içerisinde en düşük seviyeye sahip oldukları sonucuna ulaşılmıştır. Genel olarak öğrencilerin finansal okuryazarlık düzeylerinin orta ve biraz üstünde olduğu ortaya çıkmıştır.

Finansal eğitim ile ilgili ders verilen bölümlerin dışındaki diğer bölümlerde öğrenim gören öğrencilerin finansal okuryazarlık bilgi düzeylerini ölçmeyi amaçlayan çeşitli araştırmalara da rastlamak mümkündür. Dilek vd., (2016), Kastamonu merkezde bulunan fakülteler, yüksekokullar ve meslek yüksekokulunda eğitimlerine devam eden toplam 428 öğrenciye anket uygulanmıştır. Araştırma sonuçlarında, İ̈BF öğrencilerinin ekonomi okuryazarlığ bilgi düzeyleri diğer fakülte ve birimlerdeki öğrencilerin üzerinde, Beden Eğitimi ve Spor Yüksekokulu öğrencileri ise ekonomi okuryazarlığı açısından diğer öğrencilerin altında kaldığı sonuçlarına ulaşmışlardır. Cinsiyet değişkeni açısından bakıldığında ise kadınların finansal okuryazarlığı ortalaması 3.67 iken erkeklerin finansal okuryazarlığı ortalaması 3.60 'dır. Analizler sonucunda cinsiyet değişkenine göre ekonomi okuryazarlığı açısından anlamlı bir fark bulunmadığını gözlemlenmiştir.

Barmaklı ve Şener (2017), Hacettepe Üniversitesi Beytepe kampüsünde çeşitli bölümlerde öğrenim gören öğrencilerinin finansal okuryazarlık düzeylerini belirlemek amacıyla yapmışlardır. Hacettepe Üniversitesinde öğrenim gören 500 öğrenciden veri toplama aracı olarak anket yoluyla finansal okuryazarlık düzeyi sosyo-ekonomik, demografik ve tanımlayıcı özellikleri açısından incelenmiştir. Mandel (2008)'in çalışmasından yola çıkaran araştırmacılar soruların $\% 70$ ve fazlasına doğru cevap verenlerin finansal okuryazarlık düzeyi yüksek, \%50 ve \%70 arasında doğru cevap verenlerin orta, \%35 - \%50 arasında doğru cevap verenlerin düşük, 
\%35'inden azına cevap verenlerin finansal okuryazarlık düzeylerinin ise çok düşük olarak belirleneceğini belirtmişlerdir. Araştırmaya katılan öğrencilerin soruların $\% 53,62$ sine doğru cevap verdikleri ve finansal okuryazarlık düzeylerinin orta düzeyde olduğu tespit etmişlerdir. Ayrıca öğrencilerin finansal okuryazarlıkla ilgili temel para bilgisi alanında en fazla bilgiye sahip oldukları, en az bilgiye ise tasarruf ve yatırım bilgisi alanında sahip olduğunu saptamışlardır.

Mercan, Oyur ve Altınay (2012), ulaştırma bakanlığına çalışanlara yönelik olarak yaptığ 1 araştırmada anket yöntemiyle 93 kişiye NCREL'in belirlediği finansal okuryazarı bir bireyin sahip olması gereken beceriler temel alınarak taslak ölçek maddeleri geliştirerek ve katılımcılara uygulamıştır. Araştırma sonucunda araştırmaya katılan çalışanların bireysel ekonomi kullanımı boyutunda yüksek düzeyde ekonomi okuryazarı oldukları sonucuna ulaşmıştır.

Guntu ve Cihangir (2015), Osmaniye Korkut Ata Üniversitesinde çal1şan toplam 144 akademik ve idari personelin finansal okuryazarlık düzeylerini tespit etmeyi amaçladıkları çalışmalarında anket yöntemiyle veri toplamışlardır. Yapılan analiz sonuçlarına göre; çalışmaya katılanların (\% 84,7)'si Dünyadaki ve Türkiye'deki ekonomik gelişmelerle ilgilendiğini, $\% 25$ 'inin ise bu gelişmeleri her gün takip ettikleri sonuçlarına ulaşmışlardır. Ayrıca katılımcıların (\% 66,7) interneti ekonemik gelişmeleri takip etmek için kullandığını, Gazeteden takip edenlerin ise $(\% 48,6)$ ekonomifinans bölümünü okudukları belirlenmiştir. Finansal kavramlarla ilgili yeterince bilgiye sahip olduğu görülen katılımcıların, internet bankacilığını kullanma (\% 86,1), kredi kartı aylık ortalama faiz oranı bilme $(\% 60,4)$ ve kredi kartı hesap ekstresini anlama $(\% 75,7)$ gibi yüksek düzeyde bilgi sahibi olduğu sonuçlarına ulaşılmıştır.

Ülkemizde yapılan araştırmaların yanı sıra dünyada da finansal okuryazarlık ile ilgili bir çok çalışma yapıldı̆̆ı görülmektedir. Kanada da finansal okuryazarlık düzeyinin emeklilik planlaması ile olan ilişki düzeyini tespit amacıyla yaptıkları çalışmada, Kanada halkının ortalama bir bilgi düzeyine sahip olduklarını tespit etmişlerdir. Düşük eğitime sahip olma, yaşlı veya çok genç olma durumlarının ayrıca cinsiyet değişkeninin bu ortalamayı düşürdüğü sonuçlarına ulaşmışlardır. Karşılaştırma yaptıkları çalışma sonuçlarında Almanya gibi bazı ülkelerden daha düşük fa- 
kat Amerikalılarla karşılaştırıldığında Kanada halkının finansal okuryazarlık düzeylerinin daha yüksek olduğunu belirtmişlerdir ( Boisclair vd., 2017).

Idris vd., (2017) Malezyalı 430 genç üzerinde yaptıkları çalışmada, gençlerin mali sıkıntıları ile finansal okuryazarlık düzeyleri arasındaki ilişkiyi incelemişlerdir. Pozitif yönde zayıf bir ilişki tespit ettikleri çalışmada gençlerin finansalokuryazarlık düzeylerinin artmasıyla ellerindeki kaynakları daha iyi kullanabileceklerini belirtmektedirler.

Finansal okuryazarlık düzeylerinin artmasının ancak bu konuda verilecek eğitimle mümkün olacağını savunana araştırmacılardan olan Lührmann, vd., (2015) Alman liselerinde okuyan öğrencilere finansal eğitim vererek etkilerini incelemişlerdir. Eğitim uzmanlarıyla geliştirdikleri çalışma, Alışveriş, Planlama ve Tasarruf konularını içermektedir. Eğitim sonunda öğrencilerin bilgi düzeylerinin arttığın gözlemlemiş fakat bunun gerçek yaşama aktarılmasının gözlemlenemediğini bildirmişlerdir.

\section{Yöntem Ve Uygulama}

Spor Bilimleri Fakültesi öğrencilerinin finansal okuryazarlık düzeyleri ve finansal tutumların belirlemek, cinsiyet, bölüm ve aylık gelir ile finansal tutumlar arasındaki ilişkiyi tespit etmek ve bölümler arasında bir farklılık olup olmadığını analiz etmektir. Bu amaçla Atatürk Üniversitesi Spor Bilimleri Fakültesi bünyesinde yer alan Beden Eğitimi Öğretmenliği, Spor Yöneticiliği, Antrenörlük Eğitimi ve Rekreasyon bölümlerinde okuyan 1124 öğrenci anakütlesinden \% 95 güven düzeyine göre tölerans gösterilebilir \%5 hata payı ile bölüm ve sinıf düzeylerine göre iki düzeyli tabakaya ayrıldıktan sonra 290 öğrenci örneklem olarak seçilmiştir. Literatür taraması sonucunda oluşturulan anket, demografik özellikler, finansal okuryazarlık eğilimi, finansal kavramlar ve finansal tutum olmak üzere dört bölümden oluşturulmuştur. Rastgele örnekleme yöntemi ile seçilen öğrencilere hazırlanan anket uygulanmış ve elde edilen anketlerden analizde kullanılamayacak olanlar çıkarıldıktan sonra 261 anket analize dâhil edilmiştir. Analizler sonucunda, demografik özellikler, finansal okuryazarlık eğilimi ve finansal kavramlara ait frekanslar belirlendikten sonra, cinsiyet, bölüm ve aylık gelirler ile finansal tutum arasındaki ilişki Ki-Kare 
analizi ile test edilmiş son olarak da bölümler ile finansal tutum faktörleri arasında farklılık olup olmadığı Kruskal Wallis testi ile test edilmiştir.

\section{Frekans ve Yüzdeler}

Tablo 1. Demografik Özelliklere Ait Frekans ve Yüzdeler

\begin{tabular}{|c|c|c|c|}
\hline \multicolumn{2}{|c|}{ Demografik Özellik } & Frekans & Yüzde (\%) \\
\hline \multirow{3}{*}{ Cinsiyetiniz } & Kadın & 99 & 37,9 \\
\hline & Erkek & 162 & 62,1 \\
\hline & TOPLAM & 261 & 100,0 \\
\hline \multirow{5}{*}{ Yaşınız } & $17-19$ & 33 & 12,6 \\
\hline & $20-22$ & 151 & 57,9 \\
\hline & $23-25$ & 68 & 26,1 \\
\hline & 26 ve üzeri & 9 & 3,4 \\
\hline & TOPLAM & 261 & 100 \\
\hline \multirow{5}{*}{ Bölümünüz } & Bed.Eğt. Öğretmenliği & 73 & 28,0 \\
\hline & Spor Yöneticiliği & 78 & 29,9 \\
\hline & Antrenörlük Eğitimi & 58 & 22,2 \\
\hline & Rekreasyon & 52 & 19,9 \\
\hline & TOPLAM & 261 & 100 \\
\hline \multirow{5}{*}{ Sinıfinız } & 1 & 63 & 24,1 \\
\hline & 2 & 95 & 36,4 \\
\hline & 3 & 57 & 21,8 \\
\hline & 4 & 46 & 17,6 \\
\hline & TOPLAM & 261 & 100 \\
\hline \multirow{6}{*}{ Aylık Geliriniz } & 500 ve alt1 & 102 & 39,1 \\
\hline & $501-750$ & 46 & 17,6 \\
\hline & $751-1000$ & 34 & 13,0 \\
\hline & $1001-1500$ & 40 & 15,3 \\
\hline & 1501 ve üstü & 39 & 14,9 \\
\hline & TOPLAM & 261 & 100,0 \\
\hline \multirow{6}{*}{ Aylık Harcamanız } & 500 ve alt1 & 74 & 28,4 \\
\hline & $501-750$ & 85 & 32,6 \\
\hline & $751-1000$ & 39 & 14,9 \\
\hline & $1001-1500$ & 41 & 15,7 \\
\hline & 1501 ve üstü & 22 & 8,4 \\
\hline & TOPLAM & 261 & 100 \\
\hline \multirow{3}{*}{$\begin{array}{l}\text { Paranızı harcama ve yönetme ko- } \\
\text { nusunda ne kadar başarılısınız }\end{array}$} & Başarısızım & 99 & 37,9 \\
\hline & Başarılıyım & 162 & 62,1 \\
\hline & TOPLAM & 261 & 100,0 \\
\hline
\end{tabular}


Anket sonuçlarına ait frekanslar ve yüzdeleri Tablo 1'de sunulmuştur. Tablo 1 incelendiğinde, katılımcıların \% 37,9'unun kadın, \% 62,1'inin ise erkek olduğu, 17-19 yaş aralığında olanların oranının \% 12,6, 20-22 yaş grubunda $\% 57,9,23-25$ aralığında $\% 26,1$ ve 26 ve üzeri yaşta olanların ise \% 3,4 oranında olduğu görülmektedir. Katılımcıların büyük bir çoğunluğunun erkek (\%62,1) olduğu ve en yoğun yaş grubunun ise 20-22 (\% 57,9) olduğu belirlenmiştir. Ankete katılanların bölümlere göre dağılımı incelendiğinde, Beden Eğitimi Öğretmenliği \% 28, Spor Yöneticiliği \% 29,9, Antrenörlük \% 22,2 ve Rekreasyon \% 19,9'dur. Sınıfları açısından incelendiğinde ankete katılanların \% 24,1'i birinci sınıf, \% 36,4'ü ikinci sınıf, \% 21,8'i üçüncü sınıf ve \%17,6'sı dördüncü sınıfta okumaktadır. Katılımcıların aylık gelirleri incelendiğinde, 500 TL ve altı geliri olanlar \%39,1, 501750 arasinda geliri olanlar \% 17,6, 751-1000 arasinda olanlar \% 13, 10011500 arasında olanlar \% 15,3 ve 1501 ve üzeri gelire sahip olanlar \%14,9 paya sahiptir. Aylık harcama tutarlarında ise $500 \mathrm{TL}$ ve harcaması olanlar $\% 28,4,501-750$ arasinda olanlar \% 32,6, 751-1000 arasinda olanlar \% 14,9, 1001-1500 arasında olanlar \% 15,7 ve 1501 ve üzeri harcaması olanlar \% 8,4 oranındadır. Para harcama konusunda başarı düzeylerine verilen cevaplar da ise katılımcıların \% 62,1'i kendini başarılı bulurken, $\% 37,9^{\prime} \mathrm{u}$ ise başarısız olduğunu ifade etmiş̧ir.

Katılımclların faiz, nominal-reel faiz ve paranın zaman değeri bilgilerini ölçmek üzere hazırlanmış basit sorulara verdikleri cevaplara ait dağ1lımlar Tablo 2'de sunulmuştur.

Tablo 2. Finansal Bilgi Sorularına Verilen Cevapların Dă̆ılımı

\begin{tabular}{lllll}
\hline \multirow{2}{*}{ Finansal Bilgi Örnek Soruları } & \multicolumn{2}{l}{ DOĞRU } & \multicolumn{2}{l}{ YANLIŞ } \\
\cline { 2 - 5 } & Frekans & Yüzde & Frekans & Yüzde \\
\hline Faiz Bilgisi & 38 & 14,6 & 223 & 85,4 \\
\hline Nominal Faiz /Reel Faiz Bilgisi & 97 & 37,2 & 164 & 62,8 \\
\hline Paranın Zaman Değeri Bilgisi & 70 & 26,9 & 191 & 73,1 \\
\hline
\end{tabular}

Tablo 2 incelendiğinde, faiz bilgisini ölçmeye yönelik sorulan soruya katılımcıların \% 14,6's1, nominal faiz/reel faiz sorusuna \%37,2'si ve paranın zaman değeri ile ilgili soruya ise $\% 26,9^{\prime}$ u doğru cevap vermiştir. 
Spor Bilimleri Fakültesi öğrencilerinin finansal kavramlar hakkında bilgilerini ölçmek amaciyla sorulan kavramlar ve kavramlara verilen cevaplar Tablo 3'te gösterilmiştir.

Tablo 3. Finansal Kavramlar ve Cevaplara Ait Frekans ve Yüzdeler

\begin{tabular}{lllllll}
\hline \multirow{2}{*}{ Kavramlar } & \multicolumn{2}{l}{ Hiç Duymadım } & \multicolumn{2}{c}{ Duydum } & \multicolumn{2}{l}{ Bilgim Var } \\
\cline { 2 - 7 } & Frekans & Yüzde & Frekans & Yüzde & Frekans & Yüzde \\
\hline Bileşik Faiz & 150 & 57,5 & 80 & 30,7 & 31 & 11,9 \\
\hline Kredi Kartı & 9 & 3,4 & 75 & 28,7 & 177 & 67,8 \\
\hline Tasarruf & 14 & 5,4 & 71 & 27,2 & 176 & 67,4 \\
\hline Borsa İstanbul & 73 & 28,0 & 116 & 44,4 & 72 & 27,6 \\
\hline Bireysel Emeklilik & 25 & 9,6 & 113 & 43,3 & 123 & 47,1 \\
\hline Hisse Senedi & 34 & 13,0 & 122 & 46,7 & 105 & 40,2 \\
\hline Bitcoin & 103 & 39,5 & 77 & 29,5 & 81 & 31,0 \\
\hline Katılım Bankası & 78 & 29,9 & 112 & 42,9 & 71 & 27,2 \\
\hline Mevduat & 56 & 21,5 & 134 & 51,3 & 71 & 27,2 \\
\hline Döviz & 15 & 5,7 & 112 & 42,9 & 134 & 51,3 \\
\hline Merkez Bankası & 15 & 5,7 & 95 & 36,4 & 151 & 57,9 \\
\hline EFT & 30 & 11,5 & 81 & 31,0 & 150 & 57,5 \\
\hline Enflasyon & 27 & 10,3 & 121 & 46,4 & 113 & 43,3 \\
\hline Cari Açık & 94 & 36,0 & 94 & 36,0 & 73 & 28,0 \\
\hline Diş Ticaret Açı̆̆1 & 63 & 24,1 & 123 & 47,1 & 75 & 28,7 \\
\hline Risk & 47 & 18,0 & 90 & 34,5 & 124 & 47,5 \\
\hline Getiri & 38 & 14,6 & 101 & 38,7 & 122 & 46,7 \\
\hline Finansman & 31 & 11,9 & 122 & 46,7 & 108 & 41,4 \\
\hline Hazine Bonosu & 89 & 34,1 & 99 & 37,9 & 73 & 28,0 \\
\hline Ekonomik Büyüme & 32 & 12,3 & 112 & 42,9 & 117 & 44,8 \\
\hline
\end{tabular}

Tablo 3 incelendiğinde, hiç duyulmadığı ifade edilen kavramlardan ilk beş tanesinin, bileşik faiz $(\% 57,5)$, Bitcoin $(\% 39,5)$, cari açık (\%36), hazine bonosu $(\% 34,1)$ ve Borsa İstanbul $(\% 28)$ iken bilgim var denilen kavramların ilk beşinde, kredi kartı $(\% 67,8)$, tasarruf $(\% 67,4)$, merkez bankası $(\% 57,9)$, EFT $(\% 57,5)$ ve Risk $(\% 47,5)$ kavramları yer almaktadır.

Tablo 4'de Spor Bilimleri Fakültesi öğrencilerinin finansal tutum ve davranışlarını ölçmek amacıyla sorulan soruların ortalama ve mod değerlerini göstermektedir. Tablo incelendiğinde, 21. soru olan, faturalar1nızı/yurt kiranızı vb. harcamalarımı zamanında öderim sorusunun ortalamasının 3,74 ve en fazla işaretlenen şıkkın (Mod) 5 olduğu görülmektedir. 
Tablo 4. Finansal Tutum ve Davranış Ortalama ve Mod Değerleri

\begin{tabular}{lll}
\hline Soru No / Finansal Tutum ve Davranış Soruları & Ortalama & Mod \\
\hline 15. Bir ürün veya hizmet satın alırken karşılaştırma yaparım & 3,73 & 4 \\
\hline 16. Ani kararla/hareketle/dürtü ile alışveriş yaparım & 3,28 & 4 \\
\hline 17. Aylık masraflarımın yazılı ya da elektronik kaydını tutarım & 3,08 & 4 \\
\hline 18. Harcama planıma ya da planladığım bütçeye uyarım & 3,40 & 4 \\
\hline 19. Aylık bütçem yetmediğinde ek kredi (ek hesap) kullanırım & 2,92 & 4 \\
\hline 20. Tasarruf yaparak düzenli para biriktiririm & 3,18 & 4 \\
\hline 21. Faturalarınızı/yurt kiranızı vb. harcamalarımı zamanında öderim & 3,74 & 5 \\
\hline 22. Özel veya bireysel emeklilik için ödeme yaparım & 2,66 & 1 \\
\hline 23. Beklenmedik durumlarda kullanabilmek için aylık gelirimin bir & 3,30 & 4 \\
kısmını biriktiririm & &
\end{tabular}

Katılımcıların, özel veya bireysel emeklilik için ödeme yaparım soru ortalaması en düşük işaretlenen şıkkın (Mod) 1 ile "Kesinlikle katılmıyorum" olduğu tespit edilmiş ve emeklilik için ödeme yaparım sorusu 2,66 ortalama ile en düşük puana sahip olduğu tespit edilmiştir.

Anketin 15, 16, 17, 18, 19, 20 ve 23 numaralı sorularına en fazla işaretlenen şıkkın "katılıyorum" şıkkı olduğu ve bu soruların ortalamalarının 19. soru hariç 3 'ün üzerinde bir ortalamaya sahip olduğu, 19. sorunun ortalamasının ise 2,92 olduğu belirlenmiştir.

Finansal tutum ve davranışlar genel olarak değerlendirildiğinde, spor bilimleri fakültesi öğrencilerinin finansal tutum ve davranışlarının olumlu olduğu, öğrencilerin gelirlerini harcamada dikkatli davrandığı, gelirlerinin bir kısmını biriktirme eğiliminde oldukları ve ödemelerini zamanında yapmak yönünde tutum sergiledikleri görülmektedir. Fakat 16. soruda yer alan, ani kararla/hareketle/dürtü ile alışveriş yaparım sorusuna da öğrencilerin "katılıyorum" olarak çoğunlukla cevap vermeleri, tasarruf ve ürün karşılaştırma sorularına aykırı bir tutum olarak gözlenmiştir. Bu durum, öğrencilerin her ne kadar bilişsel olarak finansal tutum ve davranışlarının doğru fark ediliyor olsalar da, duygusal zeka açısından düşük bir düzeye sahip olduklarına bir gösterge olarak kabul edilebilir.

\section{Ki-Kare Analizi}

Spor Bilimleri Fakültesi öğrencilerinin cinsiyet, bölüm ve aylık gelirleri ile finansal tutum faktörleri arasındaki ilişkilerini incelemek amacıyla yapılan Ki-Kare analizi yapılmış ve sonuçlar Tablo 5'te sunulmuştur. 
Tablo 5. Ki- Kare Analizi Sonuçları

\begin{tabular}{|c|c|c|c|c|}
\hline Sorular & & $\begin{array}{l}\text { Pearson Ki-Kare } \\
\text { İstatistiği }\end{array}$ & $\begin{array}{l}\text { Serbestlik } \\
\text { Derecesi }\end{array}$ & Anlamlilık \\
\hline Cinsiyet & $\begin{array}{l}\text { 17. Aylık masraflarımın yazılı ya } \\
\text { da elektronik kaydını tutarım }\end{array}$ & $8,22^{*}$ & 4 & 0,084 \\
\hline \multirow{3}{*}{ Bölüm } & $\begin{array}{l}\text { 17. Aylık masraflarımın yazılı ya } \\
\text { da elektronik kaydını tutarım }\end{array}$ & $20,111^{*}$ & 12 & 0,065 \\
\hline & $\begin{array}{l}\text { 19. Aylık bütçem yetmediğinde } \\
\text { ek kredi (ek hesap) kullanırım }\end{array}$ & $19,004^{*}$ & 12 & 0,088 \\
\hline & $\begin{array}{l}\text { 21.Faturalarınızı/yurt kiranızı vb. } \\
\text { harcamalarımı zamanında öderim }\end{array}$ & $19,709^{*}$ & 12 & 0,073 \\
\hline \multirow{2}{*}{ Aylık Gelir } & $\begin{array}{l}\text { 16. Ani kararla/hareketle/dürtü } \\
\text { ile alışveriş yaparım }\end{array}$ & $24,281^{*}$ & 16 & 0,084 \\
\hline & $\begin{array}{l}\text { 22. Özel veya bireysel emeklilik } \\
\text { için ödeme yaparım }\end{array}$ & $26,046^{*}$ & 16 & 0,053 \\
\hline
\end{tabular}

*\% 10 önem düzeyinde anlamlılığı göstermektedir.

Katılımcıların öğrenim gördüğü bölüm değişkeni ile “(S17) Aylık masaflarımın yazılı ya da elektronik kaydını tutarım" (Pearson Ki-Kara değeri 20,111, p: 0,065), “(S19) Aylık bütçem yetmediğinde ek kredi (ek hesap) kullanırım” (Pearson Ki-Kara değeri 19,004, p: 0,088), “(S21) Faturalarınızı/yurt kiranızı vb. harcamalarımı zamanında öderim" (Pearson KiKara değeri 19,709, p: 0,073) soruları ile istatistiksel olarak \% 10 önem düzeyinde anlamlı ve pozitif yönlü bir ilişki tespit edilmiştir. Demografik özellik sırasında artışla anket skorunda artış meydana geldiğinden pozitif yönlü ilişki olduğu görülmüştür.

Katılımcların; cinsiyet, bölüm ve aylık gelirleri ile finansal tutum faktörleri arasındaki ilişkilerini incelemek amacıyla yapılan Ki-Kare analizi sonuçlarına göre, "(S17)Aylık masaflarımın yazılı ya da elektronik kaydını tutarım" soru ile Cinsiyet değişkeni (Pearson Ki-Kara değeri 8,22, p: $0,084)$ ve katılımcıların öğrenim gördügü bölüm değişkeni arasında (Pearson Ki-Kara değeri 20,111, p: 0,065), istatistiksel olarak \% 10 önem düzeyinde anlamlı ve pozitif yönlü bir ilişki tespit edilmiştir. Demografik özellik sırasında artışla anket skorunda artış meydana geldiğinden pozitif yönlü ilişki olduğu görülmüştür.

Analizler sonucunda Aylık gelir düzeyi değişkeni ile "(S16) Ani kararla/hareketle/dürtü ile alışveriş yaparım" (Pearson Ki-Kara değeri 24,281, p: 0,084), "(S22) Özel veya bireysel emeklilikiçin ödeme yaparım" 
(Pearson Ki-Kara değeri 26,046, p: 0,053) soruları arasında istatistiksel olarak \% 10 önem düzeyinde anlamlı ve pozitif yönlü bir ilişki olduğu görülmüştür. Demografik özellik sırasında artışla anket skorunda artış meydana geldiğinden ilişki yönünün pozitif olduğu tespit edilmiştir.

\section{Kruskal Wallis Testi}

Spor Bilimleri Fakültesi öğrencilerinin aylık gelir, aylık harcama ve ebeveyn eğitim durumlarına ilişkin değişkenler ile finansal tutum ve davranış faktörleri arasında bir farklılık olup olmadığı Kruskal Wallis testi ile analiz edilmiş ve analiz sonuçları Tablo 6 'da gösterilmiştir.

Tablo 6. Kruskal Wallis Testi Sonuçlarn

\begin{tabular}{|c|c|c|c|c|}
\hline İlişkili Sorular & & $\begin{array}{l}\text { Pearson Ki-Kare } \\
\text { İstatistiği }\end{array}$ & $\begin{array}{l}\text { Serbestlik } \\
\text { Derecesi }\end{array}$ & Anlamlılık \\
\hline \multirow{2}{*}{ Aylık Gelir } & $\begin{array}{l}\text { S17. Aylık masraflarımın } \\
\text { yazılı ya da elektronik } \\
\text { kaydını tutarım }\end{array}$ & $10,88^{* *}$ & 4 & 0,028 \\
\hline & $\begin{array}{l}\text { S22. Özel veya bireysel } \\
\text { emeklilik için ödeme ya- } \\
\text { parım }\end{array}$ & $10,186^{* *}$ & 4 & 0,037 \\
\hline \multirow{3}{*}{ Aylık Harcama } & $\begin{array}{l}\text { S17. Aylık masraflarımın } \\
\text { yazılı ya da elektronik } \\
\text { kaydını tutarım }\end{array}$ & $11,174^{* *}$ & 4 & 0,025 \\
\hline & $\begin{array}{l}\text { S18. Harcama planıma ya } \\
\text { da planladığım bütçeye } \\
\text { uyarım }\end{array}$ & $10,259^{* *}$ & 4 & 0,036 \\
\hline & $\begin{array}{l}\text { S19. Aylık bütçem yetme- } \\
\text { diğinde ek kredi (ek he- } \\
\text { sap) kullanırım }\end{array}$ & $15,301^{* *}$ & 4 & 0,004 \\
\hline Anne Eğitim Durumu & $\begin{array}{l}\text { S15. Bir ürün veya hizmet } \\
\text { satın alırken karşılaş- } \\
\text { tırma yaparım }\end{array}$ & $11,409^{* *}$ & 4 & 0,022 \\
\hline
\end{tabular}

** \% 5 önem düzeyinde anlamlılığ ifade etmektedir.

Yapılan analizler sonucunda Aylık Geliriniz değişkeni ile "(S17)Aylık masaflarımın yazılı ya da elektronik kaydını tutarım" (Pearson Ki-Kara değeri 10,88, p: 0,028<0,05) ve "(S22) Özel veya bireysel emeklilik için ödeme yaparım” (Pearson Ki-Kara değeri 10,186, p: 0,037<0,05) soruları 
arasında istatistiksel olarak \% 5 önem düzeyinde bir farklılık olduğu tespit edilmiştir.

Aylık Harcamanız değişkeni ile "(S17)Aylık masaflarımın yazılı ya da elektronik kaydını tutarım" (Pearson Ki-Kara değeri 11,174, p: 0,025<0,05), "(S18) Harcama planıma ya da planladığım bütçeye uyarım" (Pearson KiKara değeri 10,259, p: 0,036<0,05) ve "(S19) Aylık bütçem yetmediğinde ek kredi (ek hesap) kullanırım" (Pearson Ki-Kara değeri 15,301, p: $0,004<0,05)$ soruları arasında istatistiksel olarak \% 5 önem düzeyinde bir farklılık bulunmuştur.

Anne eğitim durumu değişkeni ile "(S15) Bir ürün veya hizmet satın alırken karşılaştırma yaparım" sorusu arasında istatistiksel olarak \% 5 önem düzeyinde bir farklılığın olduğu sonucuna varılmıştır (Pearson KiKara değeri 11,409, p: 0,022<0,05).

\section{Mann Whitney U Testi}

Katılımcıların para harcama ve yönetme konusundaki düzeylerini tespit etmek amacıyla sorulan soruya Başarısızım ve Başarılıyım şeklinde alınan cevaplar, iki seçenekli olduğundan, demografik özelliklerle farklılığını ortaya koyabilmek amaciyla Mann Whitney U testi kullanılmıştır. Mann Whitney U testi analiz sonuçları Tablo 7'de sunulmuştur.

"Aylık masraflarımın yazılı ya da elektronik kaydını tutarım" ${ }^{* * *} \mathrm{U}=$ $7478,5 ; \mathrm{p}=0,002<0,01)$. "Harcama planıma ya da planladığım bütçeye uyarım" $(* * * U=7019 ; \mathrm{p}=0,000<0,01)$, "Aylık bütçem yetmediğinde ek kredi (ek hesap) kullanırım" $\left({ }^{* * *} U=7472,5 ; p=0,002<0,01\right)$, “Tasarruf yaparak düzenli para biriktiririm" $\left.{ }^{* * *} \mathrm{U}=5984 ; \mathrm{p}=0,000<0,01\right)$, "Beklenmedik durumlarda kullanabilmek için aylık gelirimin bir kısmını biriktiririm" ${ }^{* * *} \mathrm{U}=$ 6524; $\mathrm{p}=0,000<0,01$ ), sorularına, spor bilimleri fakültesi öğrencilerinin para harcama ve yönetme becerisindeki başarılıyım cevabı veren katılımcılar ile başarısızım cevabını veren katılımcılar arasında \% $1(\mathrm{p}=<0,01)$ önem düzeyinde anlamlı farklılık bulunmaktadır.

Tablo 7. Mann Whitney U Test Sonuçlan

\begin{tabular}{llll}
\hline İlişkili Sorular & & $\begin{array}{l}\text { Mann Whitney } \\
\text { U İstatistiği }\end{array}$ & Anlamlılık \\
\hline $\begin{array}{l}\text { Para Harcama ve } \\
\text { Yönetme }\end{array}$ & $\begin{array}{l}\text { S17. Aylık masraflarımın yazılı ya } \\
\text { da elektronik kaydını tutarım }\end{array}$ & $7478,5^{* * *}$ & 0,002 \\
\hline
\end{tabular}




\begin{tabular}{|c|c|c|c|}
\hline \multirow[t]{4}{*}{ Başarısı } & $\begin{array}{l}\text { S18. Harcama planıma ya da planladı- } \\
\text { ğım bütçeye uyarım }\end{array}$ & $7019^{* * *}$ & 0,000 \\
\hline & $\begin{array}{l}\text { S19. Aylık bütçem yetmediğinde } \\
\text { ek kredi (ek hesap) kullanırım }\end{array}$ & $7472,5^{* * *}$ & 0,002 \\
\hline & $\begin{array}{l}\text { S20. Tasarruf yaparak düzenli para } \\
\text { biriktiririm }\end{array}$ & $5984^{* * *}$ & 0,000 \\
\hline & $\begin{array}{l}\text { S23. Beklenmedik durumlarda kulla- } \\
\text { nabilmek için aylık gelirimin bir } \\
\text { kısmını biriktiririm }\end{array}$ & $6524^{* * *}$ & 0,000 \\
\hline
\end{tabular}

*\% 1 önem düzeyinde anlamlılığı göstermektedir.

\section{Sonuç}

Spor Bilimleri Fakültesi öğrencilerinin finansal okuryazarlık düzeyleri ve finansal tutumlarını belirlemek, cinsiyet, bölüm ve aylık gelir ile finansal tutumlar arasındaki ilişkiyi tespit etmek ve bölümler arasında bir farklılık olup olmadığını analiz etmek amacıyla Atatürk Üniversitesi Spor Bilimleri Fakültesi öğrencilerine 290 adet anket uygulanmış, anketlerden eksik ve yanlış olanlar çıkarıldıktan sonra 261 adet anket analize tabi tutulmuştur.

Dört bölümden oluşan anketin, demografik özellikler, finansal okuryazarlık eğilimi ve finansal kavramlar hakkındaki bilgilerine ait frekanslar ve yüzdeler hesaplanmıştır. Frekanslar incelendiğinde katılımcıların \% 37,9'unun kadın, \% 62,1'inin ise erkek olduğu, 17-19 yaş aralığında olanların oranının \% 12,6, 20-22 yaş grubunda \% 57,9, 23-25 aralığında \% 26,1 ve 26 ve üzeri yaşta olanların ise \% 3,4 oranında olduğu görülmektedir. Ankete katılanların bölümlere göre dağılımı incelendiğinde, Beden Eğitimi Öğretmenliği \% 28, Spor Yöneticiliği \% 29,9, Antrenörlük \% 22,2 ve Rekreasyon \% 19,9'dir. Sınıfları açısından incelendiğinde ankete katılanların \% 24,1'i birinci sınıf, \% 36,4'ü ikinci sınıf, \% 21,8'i üçüncü sınıf ve $\% 17,6$ 'sı dördüncü sınıfta okumaktadır. Katılımcıların aylık gelirleri incelendiğinde, $500 \mathrm{TL}$ ve altı geliri olanlar \%39,1, 501-750 arasında geliri olanlar \% 17,6, 751-1000 arasinda olanlar \% 13, 1001-1500 arasinda olanlar \% 15,3 ve 1501 ve üzeri gelire sahip olanlar \%14,9 paya sahiptir. Aylık harcama tutarlarında ise 500 TL ve harcaması olanlar \%28,4, 501-750 arasında olanlar \% 32,6, 751-1000 arasinda olanlar \% 14,9, 1001-1500 arasinda olanlar \% 15,7 ve 1501 ve üzeri harcaması olanlar \% 8,4 oranındadır. Para harcama konusunda başarı düzeylerine verilen cevaplar da ise katılımcların 
\% 62,1'i kendini başarılı bulurken, \% 37,9'u ise başarısız olduğunu ifade etmiştir.

Katılımcların faiz, nominal faiz/reel faiz ve paranın zaman değeri konularındaki bilgileri ölçmek için sorulan sorulardan, faiz sorusuna kat1limcların \% 14,6'sl, nominal faiz/reel faiz sorusuna \%37,2'si ve paranın zaman değeri ile ilgili soruya ise $\% 26,9^{\prime} u$ doğru cevap vermiştir.

Katılımcıların ekonomik ve finansal bilgi düzeylerine ait cevaplar incelendiğinde, ifade edilen kavramlardan ilk beş tanesinin, bileşik faiz, Bitcoin, cari açık, hazine bonosu ve Borsa İstanbul iken bilgim var denilen kavramların ilk beşinde, kredi kartı, tasarruf, merkez bankası, EFT ve Risk kavramları yer almıştır.

Finansal tutum ve davranışlar genel olarak değerlendirildiğinde, spor bilimleri fakültesi öğrencilerinin finansal tutum ve davranışlarının olumlu olduğu, öğrencilerin gelirlerini harcamada dikkatli davrandığı, gelirlerinin bir kısmını biriktirme eğiliminde oldukları ve ödemelerini zamanında yapmak yönünde tutum sergiledikleri görülmektedir. Ani kararla/hareketle/dürtü ile alışveriş yaparım sorusuna da öğrencilerin "katılıyorum" olarak çoğunlukla cevap vermeleri, tasarruf ve ürün karşılaştırma sorularına aykırı bir tutum olarak gözlenmiştir. Bu durum, öğrencilerin her ne kadar bilişsel olarak finansal tutum ve davranışlarının doğru fark ediliyor olsalar da, duygusal zekâ açısından düşük bir düzeye sahip olduklarına bir gösterge olarak kabul edilebilir.

Spor Bilimleri Fakültesi öğrencilerinin cinsiyet, bölüm ve aylık gelirleri ile finansal tutum faktörleri arasındaki ilişkilerini incelemek amacıyla yapılan Ki-Kare analizleri sonucunda, Katılımcıların öğrenim gördüğü bölüm değişkeni ile "Aylık masaflarımın yazılı ya da elektronik kaydını tutarım”, “Aylık bütçem yetmediğinde ek kredi (ek hesap) kullanırım”, “Faturalarınızı/yurt kiranızı vb. harcamalarımı zamanında öderim" soruları ile istatistiksel olarak \% 10 önem düzeyinde anlamlı ve pozitif yönlü bir ilişki tespit edilmiştir.

Katılımcıların; cinsiyet, bölüm ve aylık gelirleri ile finansal tutum faktörleri arasındaki ilişkilerini incelemek amacıyla yapılan Ki-Kare analizi sonuçlarına göre, "Aylık masaflarımın yazılı ya da elektronik kaydını tutarım" sorusu ile Cinsiyet değişkeni ve katılımcıların öğrenim gördüğü bölüm değişkeni arasında, istatistiksel olarak \% 10 önem düzeyinde anlamlı ve pozitif yönlü bir ilişki tespit edilmiştir. 
Analizler sonucunda Aylık gelir düzeyi değişkeni ile "Ani kararla/hareketle/dürtü ile alışveriş yaparım", "Özel veya bireysel emeklilikiçin ödeme yaparım" soruları arasında istatistiksel olarak \% 10 önem düzeyinde anlamlı ve pozitif yönlü bir ilişki olduğu görülmüştür.

Öğrencilerinin aylık gelir, aylık harcama ve ebeveyn eğitim durumlarına ilişkin değişkenler ile finansal tutum ve davranış faktörleri arasında bir farklılık olup olmadığını tespit etmek amacıyla yapılan Kruskal Wallis analizi sonucunda, Aylık Geliriniz değişkeni ile "Aylık masraflarımın yazılı ya da elektronik kaydını tutarım" ve "Özel veya bireysel emeklilik için ödeme yaparım" soruları arasında istatistiksel olarak \% 5 önem düzeyinde bir farklılık olduğu tespit edilmiştir.

Aylık Harcamanız değişkeni ile "Aylık masaflarımın yazılı ya da elektronik kaydını tutarım", "Harcama planıma ya da planladığım bütçeye uyarım" ve "Aylık bütçem yetmediğinde ek kredi (ek hesap) kullanırım" soruları arasında istatistiksel olarak \% 5 önem düzeyinde bir farklılık bulunmuştur.

Anne eğitim durumu değişkeni ile "Bir ürün veya hizmet satın alırken karşılaştırma yaparım" sorusu arasında istatistiksel olarak \% 5 önem düzeyinde bir farklılığın olduğu sonucuna varılmıştır.

Mann Whitney U testi analiz sonuçlarına göre ise "Aylık masraflarımın yazılı ya da elektronik kaydını tutarım”, "Harcama planıma ya da planladığım bütçeye uyarım", "Aylık bütçem yetmediğinde ek kredi (ek hesap) kullanırım”, "Tasarruf yaparak düzenli para biriktiririm”, "Beklenmedik durumlarda kullanabilmek için aylık gelirimin bir kısmını biriktiririm" sorularına, "Para harcama ve yönetme becerisinde" başarılıyım cevabı veren katılımcılar ile başarısızım cevabını veren katılımcılar arasında \% 1 önem düzeyinde anlamlı farklılık olduğu tespit edilmiştir.

Genel olarak incelendiğinde Spor Bilimleri Fakültesi öğrencilerinin finansal okuryazarlık düzeylerinin oldukça düşük olduğu ve bölümler arasında bir farklılığın olmadığı tespit edilmiştir. Üniversitelerde finansal konularda müfredatında dersi bulunmayan fakülte ve bölümlerde, finansal okuryazarlık düzeylerinin artırılmasına yönelik olarak fakülte veya üniversite seçmeli finans derslerinin konulması bu konuda atılacak önemli bir adım olacaktır. 
EXTENDED ABSTRACT

\title{
The Determination of Level The Financial Literacy Levels of The Students of The Faculty of Sport Sciences: Atatürk University Example
}

\author{
Sevinç Namlı - Abdulkadir Kaya \\ Erzurum Technical University
}

Financial literacy consists of a combination of individual's financial knowledge and skills, behaviors and attitudes. Decisions of individuals with a high level of financial literacy on saving and investment issues will be more effective. In daily life, the right decisions to be taken by individuals in relation to their budget management, how payments can be made without interruption or how they should evaluate their savings have a linear relationship with financial literacy levels. Therefore, having to make small or large financial decisions during their lives necessitates individuals to have information about financial literacy. It is accepted that an individual who is considered to be financial literate at a basic level needs to know financial concepts such as savings, budget, credit, simple and compound interest, risk-return and inflation. From a broader perspective, it is an important criterion to know the effects of economic decisions on the individual and to have a good command of economic issues and concepts. Although some of the faculties providing undergraduate education offer courses in financial literacy education, they do not exist in some faculties such as sports sciences.

The aim of the study is to determine the financial literacy levels and financial attitudes of the students of the Faculty of Sports Sciences, to determine the relationship between gender, department and monthly income and financial holdings and to analyze whether there is a difference between the departments. For this purpose, a questionnaire was applied to students who attended Physical Education Teacher Training, Sports Management, Coaching Education and Recreation departments of Atatürk University Sports Sciences Faculty. Data from 261 surveys included 
in the analysis were subjected to frequency and percentages, Chi-square and Kruskall Wallis analyzes.

The frequencies of the demographic characteristics of the participants were examined, it was found that $37.9 \%$ of the participants were female and $62.1 \%$ were male. The ratio of those between the ages of $17-19$ was $12.6 \%, 57.9 \%$ in the $20-22$ age group, $23-2526.1 \%$ and $26 \%$ and over $3.4 \%$, respectively. The majority of the participants were male $(62.1 \%)$ and the most intensive age group was 20-22 (57.9\%). When the distribution of the participants according to the departments is examined, Physical Education Teaching is $28 \%$, Sports Management is $29.9 \%$, Coaching is $22.2 \%$ and Recreation is $19.9 \%$. When examined in terms of their classes, $24.1 \%$ of the respondents are in first grade, $36.4 \%$ are in second grade, $21.8 \%$ are in third grade and $17.6 \%$ are in fourth grade. When the monthly income of the participants is examined, those with income of 500 TL or less are $39.1 \%$, those with income between $501-750 \% 17,6$, those between $751-$ $1000 \% 13$, those between $1001-1500 \% 15.3$ and 1501 and above those having a share of $14.9 \%$. Monthly expenditure amounts are TL 500 and those with expenditures are $28.4 \%$, those between $501-750$ are $32.6 \%$, those between $751-1000$ are $14.9 \%$, those between $1001-1500$ are $15.7 \%$ and those who spend 1501 and above\% 8.4 percent. In the responses to the levels of success in spending money, $62.1 \%$ of the respondents found themselves successful and $37.9 \%$ stated that they failed.

The question asked to measure the interest information of the participants; $14.6 \%$ of the respondents, $37.2 \%$ of the nominal interest / real interest question and $26.9 \%$ of the time value of money answered correctly.

The knowledge level of the participants about basic economic concepts is examined; The first five of the concepts that were never heard were compound interest $(57.5 \%)$, Bitcoin $(39.5 \%)$, current account deficit $(36 \%)$, treasury bills (34.1\%) and Borsa İstanbul (28\%). In the first five of these concepts, credit card $(67.8 \%)$, savings $(67.4 \%)$, central bank $(57.9 \%)$, EFT $(57.5 \%)$ and Risk $(47.5 \%)$ concepts .

Tthe financial attitudes and behaviors are evaluated in general, it is seen that the students of the faculty of sports sciences have positive financial attitude and behaviors, they are careful in spending their income, they tend to accumulate some of their income and show their attitude to make their payments on time. However, in the 16th question, it was observed 
that students mostly answered orum I agree una to the question im I do shopping with sudden decision / act / impulse aykırı as an attitude contrary to saving and product comparison questions. This situation can be accepted as an indicator that students' cognitive financial attitudes and behaviors have a low level of emotional intelligence, although they are correctly recognized.

Participants; according to the results of the Chi-square analysis conducted to examine the relationship between gender, department and monthly income and financial attitude factors, the question $1 \mathrm{~m}$ I keep the written or electronic record of my monthly expenses ile and the department variable where the participants are studying are statistically significant. a significant and positive relationship was determined.

As a result of the analyzes, it was found that there is a statistically significant and positive relationship between the monthly income level variable and the questions ar I make purchases by sudden decision / act / impulse "and ödeme I pay for private or private pension".

As a result of the Kruskal Wallis analysis conducted to determine whether there is a difference between the variables related to the monthly income, monthly expenditure and parental education status of the students and financial attitude and behavior factors, the variable of iniz I keep the written or electronic record of my monthly expenses "and" Private or ar I pay for private pension ular.

There was a statistically significant difference of $5 \%$ between your Monthly Spending variable and $1 \mathrm{~m}$ I keep a written or electronic record of my monthly charges ", uyar I comply with my spending plan or my planned budget" and irım I use additional credit (additional account) when my monthly budget is not sufficient'.

It is concluded that there is a statistically significant difference between the level of education of the mother and the question ar Do I compare when purchasing a product or service 'önem.

According to Mann Whitney $U$ test analysis, $1 \mathrm{~m}$ I keep a written or electronic record of my monthly expenses ', uyar I comply with my spending plan or budget' It was found that there is a significant difference of $1 \%$ between the participants who answered $1 \mathrm{~m}$ I am successful in spending and managing skills ile and katılım I save some of my monthly income in order to use in unexpected situations'. 
In general, it was found that the financial literacy levels of the students of the Faculty of Sport Sciences were quite low and there was no difference between the departments. The introduction of faculty or university elective finance courses in order to increase the level of financial literacy in faculties and departments that do not have courses in financial subjects in universities will be an important step to be taken in this regard.

\section{Kaynakça / References}

AİM (Analitik İçgörü Merkezi) (2017). Türkiye'de finansal okuryazarlık ve erişim. https://www.teb.com.tr/upload/PDF/aile\%20akademisi\%20erisim\%20endeksi\%20raporu/TEB_FOE_Rapor_2017_12_29_online.pdf adresinden 20.03.2018 tarihinde erişilmiştir.

Alkaya, A. ve Yağlı, İ. (2015). Finansal okuryazarlık, finansal bilgi, davranış ve tutum: Nevşehir Hacı Bektaş Veli Üniversitesi İ̈BF öğrencileri üzerine bir uygulama, Uluslararası Sosyal Araştırmalar Dergisi, 8(40), 585-599.

Atkınson, A. ve Flore A. M. (2012). Measuring financial literacy - results of the OECD/ International Network On Financial Education (Infe) Pilot Study', http://www.oecd-ilibrary.org/finance-and-investment/measuring-financial-literacy_5k9csfs90fr4-en adresinden 17.04.2014 tarihinde erişilmiştir.

Barmaki, N., ve Şener, A. (2016). A Research on college students financial literacy level. Journal of Current Researches on Business and Economics, 7(2), 217-228.

Başarır, Ç., ve Sarıhan, A. Y. (2017). Üniversite öğrencilerinin finansal okuryazarlıklarının belirlenmesi: Bandırma Onyedi Eylül Üniversitesi örneği. Yönetim ve Ekonomi Araştırmaları Dergisi, 15(4 (Ek Say1)), 143-162.

Boisclair, D., Lusardi, A., ve Michaud, P. C. (2017). Financial literacy and retirement planning in Canada. Journal of Pension Economics \& Finance, 16(3), 277-296.

Chen, H., ve Volpe, R. P. (1998). An analysis of personal financial literacy among college students. Financial services review, 7(2), 107-128. 
Contuk, F. Y. (2018). Üniversite öğrencilerinin finansal okuryazarlık durumunu etkileyen faktörler üzerine bir araştırma: Muğla S1tk1 Koçman Üniversitesi örneği. Muhasebe ve Finansman Dergisi, 77, 115136.

Çam, A. V., ve Barut, A. (2015). Finansal okuryazarlık düzeyi ve davranışları: Gümüşhane üniversitesi önlisans öğrencileri üzerinde bir araştırma. Global Journal of Economics And Business Studies, 7, 63-72.

Dilek, S., Küçük, O., ve Eleren, A. (2016). Kastamonu Üniversitesi öğrencilerinin ekonomi okuryazarlığı. İnsan ve Toplum Bilimleri Araştırmaları Dergisi, 5(7), 1865-1878.

Er, B., Şahin, Y. E., ve Mutlu, M. (2017). Finansal eylem ve finansal okuryazarlık: üniversite öğrencilerine yönelik bir araştırma. Finans Politik \& Ekonomik Yorumlar, 54(630), 75-88.

Gerek, S., ve Kurt, A. (2008). Economic literacy of university students: A sample from Anadolu University. Available at SSRN: https://ssrn.com/abstract $=1137610$

Gökmen, H., (2012). Finansal okuryazarlik, İstanbul:Hiperlink Yayınları.

Gönen, E., ve Özmete, E. (2007). Finansal refah: Finansal yönetim sürecinden duyulan tatmin, finansal davranışlar ile öz-saygı arasındaki ilişkinin incelenmesi. Sosyal Politika Çalışmaları Dergisi, 3(11), 5769.

Gutnu, M. M., ve Cihangir, M. (2015). Finansal okuryazarlık: Osmaniye Korkut Ata Üniversitesi personeli üzerinde bir araştırma. The Journal of Academic Social Science, 3(10), 415-424.

Idris, F. H., Krishnan, K. S. D., ve Azmi, N. (2017). Relationship between financial literacy and financial distress among youths in MalaysiaAn empirical study. Geografia-Malaysian Journal of Society and Space, 9(4), 106-117.

Lusardi, A., ve Mitchell, O. S. (2007). Baby boomer retirement security: The roles of planning, financial literacy, and housing wealth. Journal of monetary Economics, 54(1), 205-224.

Lührmann, M., Serra-Garcia, M., ve Winter, J. (2015). Teaching teenagers in finance: does it work?. Journal of Banking \& Finance, 54, 160-174.

Mercan, N., Oyur, E., Altınay, A. ve Aksanyar, Y. (2012). Ekonomi okur yazarlığına yönelik ampirik bir araştırma. Ekonomi Bilimleri Dergisi, 4(2), 109-118. 
Özer, M. (2005). İktisadın tanımı ve temel kavramları. (İ.Şıklar,Ed.), İktisada giriş içinde (s.1-25). Eskişehir: Anadolu Üniversitesi Yayınları. SarıgüL, H . (2015). Finansal okuryazarlık tutum ve davranış ölçeği: Geliştirme, geçerlik ve güvenirlik. Yönetim Ve Ekonomi Araştırmaları Dergisi, 13 (1), 200-218.

Temizel, F., ve Bayram, F. (2011). Finansal okuryazarlık: Anadolu Üniversitesi İktisadi İdari Bilimler Fakültesi (İ̈BF) öğrencilerine yönelik bir araştırma. CÜ İktisadi ve İdari Bilimler Dergisi, 12(1), 73-86.

Worthington, A. (2006). Predicting financial literacy in Australia. Financial Services Review, 15(1), 59-79.

Yardımcıoğlu, M., Akpınar, Y., ve Günay, Y. (2014). Vergi okuryazarlığı ve vergisel farkındalık: Kahramanmaraş araştırması. Kahramanmaraş Sütçü İmam Üniversitesi İktisadi ve İdari Bilimler Fakültesi Dergisi, 4(2), 95-119.

\section{Kaynakça Bilgisi / Citation Information}

Namlı, S. ve Kaya, A. (2019). Spor bilimleri fakültesi öğrencilerinin finansal okuryazarlik düzeylerinin tespiti: Atatürk Üniversitesi örneği . OPUS-Uluslararası Toplum Araştırmaları Dergisi, 13(19), 960-982. DOI: $10.26466 /$ opus.601969 